\title{
When Should Renal Replacement Therapy for Acute Kidney Injury Be Initiated and Discontinued?
}

\author{
R.T. Noel Gibney ${ }^{a, c}$ S.M. Bagshaw ${ }^{a, c}$ D.J. Kutsogiannis ${ }^{a, d} \quad$ C. Johnston ${ }^{a, b, d}$ \\ a Division of Critical Care Medicine, ${ }^{b}$ Division of Nephrology, Department of Medicine, Faculty of Medicine \\ and Dentistry, University of Alberta, ' ${ }^{C}$ General Systems Intensive Care Unit, University of Alberta Hospital, and \\ dIntensive Care Unit, Royal Alexandra Hospital, Edmonton, Alta., Canada
}

\section{Key Words}

Hemodialysis · Hemofiltration · Continuous renal replacement therapy $\cdot$ Acute renal failure $\cdot$ Acute kidney injury $\cdot$ Volume overload $\cdot$ Hyperkalemia

\begin{abstract}
Background: Critically ill patients with acute kidney injury (AKI) are at high risk for death and frequently require initiation of renal replacement therapy (RRT). There is wide variation in clinical practice on the indications for and timing of initiation and discontinuation of RRT. Numerous clinical and biochemical factors (i.e. uremic, metabolic, fluid balance) have been used; however, at present there is no consensus to guide clinicians on the most favorable time to initiate and/ or discontinue RRT to optimize patient outcomes. Methods: In this review, we appraise the available clinical studies that have assessed timing of initiation and/or discontinuation of RRT for critically ill patients with AKI. 'Timing' of initiation has been variably defined including use of conventional biomarkers (i.e. serum urea and creatinine), urine output, fluid balance, and time relative to intensive care unit admission.
\end{abstract}

Conclusions: Numerous studies consistently point toward a survival benefit to early initiation of RRT; however, there is a paucity of high-quality randomized trials. If early RRT is associated with clinical benefit, it remains uncertain whether this is attributable to more rapid metabolic/uremic control, management of fluid balance or a combination of clinical factors. In addition, timing of RRT initiation is likely contextspecific and varies by clinical factors and/or etiology of AKI. There is also little data to accurately distinguish in advance between the injured kidney that will need extracorporeal renal support and one that retains capacity for early recovery. Fewer studies have evaluated the process of weaning of RRT or ideal methods to predict sufficient recovery to avoid reinitiation. Longer duration of RRT support, higher illness severity and lower urine output (independent of diuretic therapy) have all predicted need for re-initiation. Additional investigations on these issues are clearly warranted and urgently needed.

Copyright $\odot 2008$ S. Karger AG, Basel

\section{KARGER}

Fax +41613061234 E-Mail karger@karger.ch www.karger.com
(C) 2008 S. Karger AG, Base

0253-5068/08/0265-0473\$24.50/0

Accessible online at:

www.karger.com/bpu
Dr. R.T. Noel Gibney

Division of Critical Care Medicine, 3C1.16 Walter C. Mackenzie Centre

8440-112 Street, Edmonton, Alta. T6G 2B7 (Canada)

Tel +1 780407 6755, Fax +1 7804071228

E-Mail ngibney@ualberta.ca 


\section{Introduction}

Despite the longstanding and widespread use of renal replacement therapy (RRT) in acute kidney injury (AKI), there remains controversy about the optimal delivery of RRT, especially with respect to dose prescription and mode [1-16]. In practice, however, the provision of RRT in patients with AKI is extremely variable and based primarily on empiricism, local institutional practice and resources [17-22]. Evidence for the benefit of RRT in the acute setting is based largely on the known and highly lethal outcome of untreated AKI before the availability of extracorporeal dialysis, on early case series, and on extrapolation of the experience in chronic kidney disease (CKD) [23-25]. However, evidence on long-term followup of patients with AKI is limited. While the application of RRT improves short-term survival in patients with severe AKI, emerging data also suggests the long-term prognosis may be modified by AKI and characterized by impartial or non-recovery of kidney function, progression to CKD and greater long-term risk of death in survivors [26-28].

The use of newer classification systems, such as the RIFLE criteria, which have now been extensively validated, will greatly help to provide a more consistent approach to the comparative evaluation and research investigation for critically ill patients with AKI [29-40]. There is also strong evidence not only that the development of $\mathrm{AKI}$ is an independent factor for mortality in critically ill patients, but also that increasing severity of AKI, as measured by RIFLE classification, is directly associated with higher mortality [32-34, 40-42].

Despite this emerging agreement on the definition and impact of AKI, there remains no consensus on the optimal time to initiate or discontinue RRT in terms of serum biomarkers (i.e. creatinine, urea), fluid volume status or RIFLE staging. Since the natural history of AKI also varies by the cause, the effect of early initiation of RRT may also be influenced by the etiology of the AKI [43]. In general, there is agreement that RRT should be initiated as 'rescue therapy' when patients develop life-threatening complications associated with acute renal failure (i.e. hyperkalemia, pulmonary edema, uremic complications). However, outside of these indications, there is little consensus to guide clinicians on the appropriate time for initiation and discontinuation of RRT [32, 33, 44-51]. In reality, local resources including staffing, machine availability, and budget have a major influence on RRT resources such as timing of initiation, dose and frequency of RRT. In this review, we discuss the available data on the optimal time for the initiation and discontinuation of RRT in critically ill patients with AKI.

\section{When Should Acute Extracorporeal Renal Support Be Initiated?}

While there is general agreement on the value of RRT in established AKI, in particular when associated with oligoanuria, there is little agreement with regard to the optimal time of initiation and there is no accepted definition of what 'timing of initiation' represents. Currently, the term 'timing' for RRT may be variably interpreted as the timing from hospital admission, timing from ICU admission or timing from acute insult or, more commonly, as a proxy for timing when using arbitrary biochemical thresholds for serum urea and/or creatinine or measures of fluid balance $[48,52-63]$. Consequently, there is wide variation in clinical practice [1722].

\section{'Timing' of RRT Initiation Defined by Surrogate Biochemical Markers}

The majority of the literature on timing of RRT initiation uses threshold serum levels of urea or creatinine [64]. The assumption is that uremic illness is due to the accumulation of organic waste factors, not all understood, that are normally cleared by the kidney but are toxic to the patient [65]. With a paucity of clinical trials to guide timing of initiation of RRT, clinicians are left to make inferences based on retrospective studies with historical controls and cohort studies of variable quality. In a seminal study comparing randomized controlled trials with studies using historical controls across six therapeutic topics, Sacks et al. [66] showed that studies incorporating historical controls were more likely than randomized trials to find a therapeutic difference despite similar outcomes in the treatment group. Since many of the older studies on the timing of RRT incorporate historical controls, it is important to view the results in the context of this potential bias.

Teschan et al. [24] introduced the idea of 'prophylactic dialysis' in soldiers injured during the Korean War. In 15 patients with acute oliguric renal failure, hemodialysis was 'prophylactically' initiated at blood urea nitrogen (BUN) values $\leq 100 \mathrm{mg} / \mathrm{dl}$ (serum urea 35.7 $\mathrm{mmol} / \mathrm{l})$. Overall mortality in this series was only $33 \%$. 
While not a randomized trial, the authors concluded that the mortality in these patients was significantly lower than their previous historical experience where hemodialysis was typically initiated for more traditional 'rescue therapy' indications such as the development of uremic complications, hyperkalemia and/or pulmonary edema.

In the 1960s and 1970s, similar improvements in clinical outcome with early and/or more intensive hemodialysis were described [67-70] (table 1). In a small nonrandomized study enrolling 33 patients with postoperative AKI, Parsons et al. [70] showed earlier (BUN $\leq 120-152 \mathrm{mg} / \mathrm{dl}$ [urea $43-54 \mathrm{mmol} / \mathrm{l}$ ]) as compared with later (BUN $\geq 200 \mathrm{mg} / \mathrm{dl}$ [urea $71 \mathrm{mmol} / \mathrm{l}$ ]) initiation of hemodialysis was associated with a significant reduction in the risk of death $(25 \%$ for early vs. $88 \%$ for late, risk ratio [RR] 0.16, 95\% CI 0.04-0.60, p < 0.001). Several additional small studies found comparable benefit with earlier initiation of intermittent hemodialysis (IHD), defined by lower BUN levels, in patients with AKI. Fischer et al. [67] retrospectively analyzed data from 162 patients with AKI requiring IHD and classified those started on RRT with a BUN $<150 \mathrm{mg} / \mathrm{dl}$ (urea $54 \mathrm{mmol} / \mathrm{l}$ ) as early and those with a BUN $>200 \mathrm{mg} / \mathrm{dl}$ (urea $71 \mathrm{mmol} / \mathrm{l}$ ) as delayed. Survival in the early RRT group was $46 \%$ compared with only $26 \%$ in the delayed RRT group. During the Vietnam War, Conger [71] studied 18 soldiers with posttraumatic AKI. Patients were assigned alternately to intensive IHD to maintain a predialysis BUN $<70 \mathrm{mg} / \mathrm{dl}$ (urea $25 \mathrm{mmol} / \mathrm{l})$ and serum creatinine $<5 \mathrm{mg} / \mathrm{dl}(442$ $\mu \mathrm{mol} / \mathrm{l})$, or to a non-intensive IHD regimen aimed to maintain a BUN $<150 \mathrm{mg} / \mathrm{dl}$ (urea $54 \mathrm{mmol} / \mathrm{l}$ ), a serum creatinine $<10 \mathrm{mg} / \mathrm{dl}(884 \mu \mathrm{mol} / \mathrm{l})$ and for treatment of any life-threatening clinical indications for dialysis. Five of 8 patients (64\%) survived in the intensive IHD group compared to 2 of 10 (20\%) in the non-intensive IHD group $(p<0.14)$. In addition to the apparent survival benefit, major complications, including gastrointestinal bleeding and sepsis, were less frequent in the intensive IHD group [71]. Kleinknecht et al. [69] reported a large cohort of 500 patients with AKI treated between 1966 and 1970. 'Prophylactic' hemodialysis to maintain a serum BUN $<92$ $\mathrm{mg} / \mathrm{dl}$ (urea $33 \mathrm{mmol} / \mathrm{l}$ ) was provided to 221 patients and compared with 279 historical controls who received usual care in which hemodialysis was initiated if the BUN was $>165 \mathrm{mg} / \mathrm{dl}$ (urea $59 \mathrm{mmol} / \mathrm{l}$ ) or in the presence of other acute indications (i.e. severe electrolyte disturbance). Those treated with earlier 'prophylactic' hemodi-

Table 1. Summary of clinical studies evaluating timing of RRT initiation by BUN concentrations in critically ill patients with AKI and the association with clinical outcome

\begin{tabular}{|c|c|c|c|c|c|c|c|}
\hline \multirow[t]{2}{*}{ Study } & \multirow[t]{2}{*}{ Year } & \multirow[t]{2}{*}{ Number } & \multirow{2}{*}{$\begin{array}{l}\text { Study } \\
\text { design }\end{array}$} & \multicolumn{2}{|c|}{ BUN, mg/dl } & \multicolumn{2}{|c|}{ Mortality, \% } \\
\hline & & & & early & delayed & early & delayed \\
\hline Parsons [70] & 1961 & 33 & $\mathrm{R}$ & $43-54$ & $>72$ & 25 & 88 \\
\hline Fischer [67] & 1966 & 162 & $\mathrm{R}$ & 54 & $>72$ & 57 & 74 \\
\hline Kleinknecht [69] & 1972 & 500 & $\mathrm{R}$ & 33 & 59 & 29 & 42 \\
\hline Conger $[71]$ & 1975 & 18 & $\mathrm{P}, \mathrm{C}$ & 18 & 43 & 20 & 64 \\
\hline Gillum [68] & 1986 & 34 & $\mathrm{P}, \mathrm{C}$ & 22 & 36 & 59 & 47 \\
\hline Lange [102] & 1987 & 36 & $\mathrm{R}$ & $<80$ & $>80$ & 43 & 67 \\
\hline Gettings [57] & 1999 & 100 & $\mathrm{R}$ & 43 & 95 & 61 & 80 \\
\hline Bouman [46] & 2002 & 106 & RCT & 45 & 105 & 29 & 25 \\
\hline Tsai [103] & 2005 & 98 & $\mathrm{R}$ & $<80$ & $>80$ & 63 & 97 \\
\hline Liu [59] & 2006 & 243 & $\mathrm{P}, \mathrm{C}$ & $<76$ & $>76$ & 35 & 41 \\
\hline Bagshaw [45] & 2008 & 1,238 & $\mathrm{P}, \mathrm{C}$ & $<68$ & $>68$ & 63 & 61 \\
\hline
\end{tabular}

$\mathrm{P}=$ Prospective, $\mathrm{R}=$ retrospective $\mathrm{C}=$ cohort $\mathrm{RCT}=$ randomized clinical trial.

To convert BUN (mg/dl) to urea (mmol/l) multiply by 0.357 . 
alysis experienced fewer uremic complications and had a $30 \%$ lower risk of death (RR $0.70,95 \%$ CI $0.54-0.89, \mathrm{p}<$ $0.01)$.

However, the study by Gillum et al. [68] showed no benefit with early RRT. In this small randomized trial of 34 patients with AKI, patients were allocated to receive either 'intensive' hemodialysis to maintain BUN $<60 \mathrm{mg} / \mathrm{dl}(<21 \mathrm{mmol} / \mathrm{l})$ and serum creatinine $<5 \mathrm{mg} / \mathrm{dl}$ $(<442 \mu \mathrm{mol} / \mathrm{l})$ or to a 'less intensive' regimen to maintain BUN $<100 \mathrm{mg} / \mathrm{dl}(<36 \mathrm{mmol} / \mathrm{l})$ and serum creatinine $<9 \mathrm{mg} / \mathrm{dl}(<796 \mu \mathrm{mol} / \mathrm{l})$. There were no significant differences in survival between the intensive and less intensive groups; however, this trial was not really designed to evaluate the timing of initiation of RRT. Notably, all patients had serum creatinine values $\geq 8 \mathrm{mg} / \mathrm{dl}$ $(\geq 707 \mu \mathrm{mol} / \mathrm{l})$ at the time RRT was initiated. In addition, there were marked differences in illness severity between the groups, making inferences about timing difficult.

Within the last decade, two retrospective observational studies have shown improved survival when RRT was initiated early when defined arbitrarily by lower serum urea levels $[57,59]$. In a small cohort of critically ill patients with posttraumatic AKI receiving continuous RRT, Gettings et al. [57] used a cut-off of a BUN $\geq 60 \mathrm{mg} / \mathrm{dl}$ $(\geq 21.4 \mathrm{mmol} / \mathrm{l})$ to evaluate the impact of early vs. delayed 'timing' of intervention on survival. The 'early' group had a mean BUN $42.6 \mathrm{mg} / \mathrm{dl}(15.2 \mathrm{mmol} / \mathrm{l})$ compared with the 'delayed' group having a mean BUN $94.5 \mathrm{mg} / \mathrm{dl}$ (33.7 $\mathrm{mmol} / \mathrm{l})(\mathrm{p}<0.0001)$. Both the early and delayed groups, however, likely had relatively late RRT initiation. The 'early' group had CRRT (continuous RRT) initiated 10 days after hospital admission whereas the 'delayed' had RRT started 19.4 days after presentation. The overall mortality for the entire cohort was high; however, the mortality for early compared with delayed RRT was significantly lower (61\% for early vs. $80 \%$ for delayed; RR $0.77,95 \%$ CI $0.58-1.0, \mathrm{p}=0.04)$.

In a more recent secondary analysis of a prospectively collected AKI database, Liu et al. [59] found a significant higher risk of death at 60 days when initiation of RRT was delayed, defined by a serum urea level $\geq 76 \mathrm{mg} / \mathrm{dl}$ ( $\geq 27.1$ $\mathrm{mmol} / \mathrm{l})$, compared with earlier commencement. After covariate adjustment in multivariable analysis, including for age, hepatic failure, sepsis, thrombocytopenia, serum creatinine, study site and initial dialysis modality, the RR for death associated with delayed initiation of RRT was 1.85 (95\% CI 1.16-2.96) [59].

In the classic CVVH (continuous veno-venous hemofiltration) dose trial by Ronco et al. [10], where survival was significantly improved in those patients treated with $35 \mathrm{ml} / \mathrm{kg} / \mathrm{h}$ when compared with $20 \mathrm{ml} / \mathrm{kg} / \mathrm{h}$, a higher $\mathrm{BUN}$ at the time of initiation of CVVH was independently associated with lower survival (adjusted hazards ratio [HR] 1.05, 95\% CI 1.04-1.07). Similarly, in the dose trial by Saudan et al. [11], comparing CVVH with CVVHDF (CVV hemodiafiltration), baseline BUN was found to be independently associated with 28-day and 90-day mortality $(\mathrm{p}=0.008)$.

These data would indicate that earlier initiation of RRT, prior to significant retention of uremic solutes, potentially exerts an important influence on survival that is also independent of therapeutic RRT dose prescribed. However, only one small and underpowered randomized trial has evaluated the impact of both timing and dose on clinical outcome [46]. Bouman et al. [46] examined the effect of timing of CVVH on outcome in 106 critically ill ventilated patients with oliguric AKI, and found no significant benefit to early or high-intensity CVVH whether timing was defined by either time from development of oliguria or by BUN threshold. However, inferences from this study are limited due to the small sample size, the predominantly cardiac surgical population and the surprisingly high survival rate (i.e. low mortality event rate).

\section{'Timing' of RRT Initiation Defined by Time of Onset of Oliguria}

Sugahara et al. [63] employed urine output as a criterion for initiation of CRRT in a small randomized trial of 28 critically ill patients following cardiac surgery. Patients were enrolled when urine output fell below $30 \mathrm{ml} / \mathrm{h}$ and the serum creatinine increased $\geq 0.5 \mathrm{mg} / \mathrm{dl}$ ( $\geq 44.2$ $\mu \mathrm{mol} / \mathrm{l})$ within $24 \mathrm{~h}$. The early initiation group $(\mathrm{n}=14)$ had RRT started when urine output was $<30 \mathrm{ml} / \mathrm{h}$ for three consecutive hours (daily urine output $<750 \mathrm{ml}$ ). The delayed group $(\mathrm{n}=14)$ had CRRT started when urine output reached $<20 \mathrm{ml} / \mathrm{h}$ for two consecutive hours (daily urine output $<500 \mathrm{ml}$ ). At baseline, the early and delayed groups were well matched, including for serum creatinine and illness severity. Mean urine output was preserved for the first several days in the early start group and began to increase on day 6 of CVVHD (CVV hemodialysis), with a difference from baseline becoming significant by day 8 . In the delayed start group, the mean urine output decreased during the first 3 days of CVVHD and, although it increased subsequently, the change from baseline was never significant over the 14-day period of 
evaluation. Moreover, survival at 14 days was significantly higher in the early group vs. the delayed group (86 vs. $14 \%, \mathrm{p}<0.01)$.

\section{'Timing' of RRT Initiation Defined by Duration from ICU Admission}

While the majority of studies have generally used a metabolic/solute threshold such as serum urea as a proxy for timing of initiation of RRT, there is some evidence that timing of RRT in critically ill patients with AKI relative to admission to ICU may have prognostic importance. Cosentino et al. [54] found, in a cohort of 363 critically ill patients with AKI, that temporal delay from ICU admission to start of RRT (i.e. increase in the number of days) was independently associated with mortality.

Three retrospective single-center studies of critically ill patients with AKI following cardiac surgery have shown improved survival with earlier initiation of CRRT, defined temporally as the number of hours/days after surgery [55, 56, 72]. Bent et al. [72] compared 65 consecutive patients who developed AKI following cardiac surgery treated with early intensive CVVH to historical controls. The average time between surgery and the start of CVVH was 2.4 days. The predicted mortality in this population was $66 \%$, based on the Liano prediction model, while the observed mortality was only $40 \%(\mathrm{p}=0.003)$, suggesting early intensive RRT for AKI complicating cardiac surgery can improve survival [73]. Elahi et al. [56] evaluated the impact of initiation of RRT early in the postoperative period for critically ill cardiac surgery patients with AKI. Of the 1,264 patients who had cardiac surgery over a 1-year period, $64(5 \%)$ required RRT for AKI. Patients were divided into two categories: 'early CRRT' defined by initiation of CRRT when the urine output reached $\leq 100 \mathrm{ml}$ during a consecutive 8 -hour period, regardless of the biochemical parameters, and 'delayed CRRT' defined by initiation of CRRT upon fulfilling any of the following criteria: BUN $\geq 84 \mathrm{mg} / \mathrm{dl}$ ( $\geq 30 \mathrm{mmol} / \mathrm{l}$ ), creatinine $\geq 2.8 \mathrm{mg} / \mathrm{dl}$ ( $\geq 248$ $\mu \mathrm{mol} / \mathrm{l}$ ), or potassium $\geq 6.0 \mathrm{mmol} / \mathrm{l}$, regardless of urine output. Overall, this cohort was characterized by relatively advanced age (mean 70 years), and a high prevalence of both congestive heart failure (56\% NYHA class 3 or 4) and CKD (baseline creatinine $1.8 \mathrm{mg} / \mathrm{dl}[159$ $\mu \mathrm{mol} / \mathrm{l}])$. The average time to CRRT initiation after surgery was $18 \mathrm{~h}$ in the early CRRT group compared with $61.2 \mathrm{~h}$ in the delayed CRRT group $(\mathrm{p}<0.001)$. This dif- ference in 'timing' was associated with a significantly lower BUN in the early vs. delayed group $(67 \mathrm{mg} / \mathrm{dl}[23.9$ $\mathrm{mmol} / \mathrm{l}]$ vs. $75 \mathrm{mg} / \mathrm{dl}$ [26.8 $\mathrm{mmol} / \mathrm{l}], \mathrm{p}<0.05)$, respectively. While the median duration of CRRT was similar between the two groups, the early CRRT group had a significantly lower hospital mortality compared with those receiving delayed CRRT ( $22 \%$ for early vs. $43 \%$ for late, $\mathrm{p}<0.05)$. This may, in part, be attributable to a lower rate of multiorgan failure developing in the early CRRT group compared with those that were delayed CRRT (19\% for early vs. $29 \%$ for late, $p=0.01$ ). Furthermore, the average duration of ICU and hospital stay were both significantly reduced in those re ceiving early CRRT (8.5 days in ICU for early vs. 12.5 days for delayed, $\mathrm{p}<0.05 ; 15.4$ days in hospital for early vs. 20.9 days for delayed, $\mathrm{p}<0.05$ ). In a nearly identical clinical study, Demirkilic et al. [55] evaluated early intensive CVVHDF compared with conservative usage of CVVHDF in 61 critically ill patients with AKI after cardiac surgery and found similar results. The average time between surgery and initiation of CVVHDF was $61 \mathrm{~h}$ in the delayed group compared with $19.2 \mathrm{~h}$ in the early group $(p=0.0001)$. Likewise, the average length of stay in ICU was considerably shorter for early CRRT compared with delayed (7.9 days for early vs. 12 days for delayed, $p=0.0001)$. Finally, both ICU and hospital mortality were higher for delayed CRRT when compared with early CRRT (ICU: $48.1 \%$ for delayed vs. $17.6 \%$ for early, $\mathrm{p}=0.014$; hospital: $55.5 \%$ for delayed vs. $23.5 \%$ for early, $p=0.016$ ). As with the study of Bent et al. [72], the delayed group in this study were historical controls, which limits inferences.

More recently, in a small observational study with historical controls, Andrade et al. [52] compared outcomes based on the 'door-to-dialysis' time and frequency of IHD in critically ill patients with leptospirosis-induced AKI, septic shock and multiorgan dysfunction. Patients were compared by treatment strategies of either alternate day IHD and daily IHD. While there was no difference between the groups in BUN levels at the time of RRT initiation, a shorter measured 'door-to-dialysis' time and daily IHD was associated with significantly higher survival compared with delayed and alternate day IHD (83.3\% for early and daily vs. $33.3 \%$ for delayed and alternate day). However, inferences are limited due to issues of study design and confounding.

Recently, the Beginning and Ending Supportive Therapy for the Kidney (BEST) investigators reported findings from a secondary analysis of their database on the timing of RRT and clinical outcomes in 1,238 critically ill 
patients [45]. The BEST Kidney Study was a prospective, multinational, multicenter observational cohort study of critically ill patients with severe AKI performed at 54 centers across 23 countries [51]. This analysis found important differences in clinical outcomes when 'timing' of initiation of RRT was defined by median values of serum urea, serum creatinine or temporally from the date of ICU admission. Timing of RRT was stratified into 'early' and 'late' by median serum urea and creatinine levels at the time RRT was started. Timing was also categorized temporally from ICU admission into early ( $<2$ days), delayed ( $2-5$ days), and late ( $>5$ days). Timing of RRT by serum urea at RRT initiation showed no significant difference in crude or covariate-adjusted mortality. When stratified by serum creatinine, late RRT was associated with lower crude mortality $(53.4 \%$ for creatinine $>3.5$ $\mathrm{mg} / \mathrm{dl}[309 \mu \mathrm{mol} / \mathrm{l}] \mathrm{vs} .71 .4 \%$ for creatinine $\leq 3.5 \mathrm{mg} / \mathrm{dl}$ [309 $\mu \mathrm{mol} / \mathrm{l}]$; OR 0.46; 95\% CI 0.36-0.58, p < 0.001) and covariate-adjusted mortality (OR $0.51,95 \%$ CI $0.37-0.69$, $\mathrm{p}<0.001)$. However, for 'timing' relative to ICU admission, late RRT was associated with greater crude mortality $(72.8 \%$ for late vs. $62.3 \%$ for delayed vs. $59 \%$ for early, $\mathrm{p}<0.001)$ and covariate-adjusted mortality (OR 1.95, $95 \%$ CI 1.30-2.92, $\mathrm{p}=0.001)$. Overall, late RRT, however defined, was also associated with a longer duration of RRT, longer stay in hospital and a lower rate of renal recovery to dialysis independence at hospital discharge [45].

The recently reported ATN study, a large multicenter randomized trial of 1,124 critically ill patients with AKI, showed no meaningful difference in 60-day mortality between intensive and less intensive RRT (53.6\% for intensive vs. $51.5 \%$ for less intensive, $p=0.47$ ). However, while the average BUN values were nearly identical at RRT initiation $(65.9 \mathrm{mg} / \mathrm{dl}$ [23.5 mmol/l] vs. $66.7 \mathrm{mg} / \mathrm{dl}$ [23.8 $\mathrm{mmol} / \mathrm{l}]$ ), regardless of modality, it is noteworthy that the average time from ICU admission to RRT initiation was $\geq 6$ days in both groups [13]. Similarly, in the randomized trial by Tolwani et al. [109] comparing high-dose to standard-dose CVVHDF in 200 critically ill patients with AKI, the average time from ICU admission to RRT initiation was 8 days. These data are in contrast with the BEST Kidney Study and the trial by Ronco et al. where the average time from ICU admission to RRT initiation was 1-1.6 days, respectively $[10,45]$.

\section{'Timing' of RRT Based on Fluid Volume Status}

There is clear consensus on the importance of fluid therapy in the acute resuscitation of critically ill patients [74]. Moreover, the administration of fluid therapy is common and it is likely that all patients receive variable amounts of intravenous fluid therapy during an episode of critical illness. Fluid therapy also represents a central cornerstone for the prevention and/or the management of AKI in critical illness [75, 76]. Of the numerous strategies evaluated to date for the prevention of AKI, only fluid therapy has been found consistently effective [75]. However, there is no evidence fluid therapy will reverse AKI once established. In fact, evidence has accrued to indicate that the unnecessary accumulation of fluid (i.e. fluid overload) can negatively impact clinical outcomes in critically ill patients [77-79]. This may be particularly evident for fluid overloaded oliguric patients with AKI who fail to adequately respond to a diuretic challenge.

In addition, the avoidance of volume overload represents a huge clinical challenge in the critically ill, in particular for those with AKI, and represents a common indication for RRT [80-85]. Similarly, oliguria in AKI, in the absence of clear hypovolemia, is not necessarily an indication for a fluid challenge. The distinction is important. In the context of hypovolemia and/or reduced effective circulating volume, fluid therapy is clearly indicated. However, there is no evidence to support a fluid challenge in the resuscitated critically ill patient with oliguric AKI. While such a fluid challenge may indeed temporarily increase urine flow, there is no data to indicate that such a fluid challenge attenuates the severity of AKI or improves clinical outcome. Instead, the liberal use of fluid therapy in these circumstances may contribute to or exacerbate volume overload and lead to harm (table 2). For example, in a small cohort of critically ill patients with sepsis-induced AKI, Van Biesen et al. [77] found that, despite resuscitation characterized by optimal hemodynamics and restored intravascular volume and despite an already high use of diuretic therapy, additional fluid therapy not only failed to improve kidney function but led to unnecessary volume overload, impaired gas exchange and pulmonary edema.

Recently, Upadya et al. [86] found that maintenance of a negative fluid balance independently predicted weaning success in critically ill mechanically ventilated patients. Likewise, several studies have now shown improved survival, fewer ventilator-days and/or reduced duration of ICU stay in patients with ARDS/ALI by 
adopting a conservative fluid management strategy essentially aimed at maintaining a neutral fluid balance $[78,79]$. In a small retrospective study, Alsous et al. [87] found an increased risk of death for critically ill patients with septic shock failing to achieve a negative fluid bal- ance within the first 3 days of treatment (RR 5.0, 95\% CI $2.3-10.9, \mathrm{p}<0.0001)$.

Moreover, emerging data would suggest that avoidance of fluid overload with CRRT can improve clinical outcomes, especially in critically ill children with AKI

Table 2. Summary of clinical studies showing an association between fluid balance and clinical outcome

\begin{tabular}{|c|c|c|c|c|c|c|}
\hline Study & Year & Patients & Design & Population & Intervention & Outcome \\
\hline Simmons [104] & 1987 & 113 & $\mathrm{P}, \mathrm{C}$ & ARDS & N/A & $\begin{array}{l}\text { Mortality associated with positive daily/ } \\
\text { cumulative fluid balance and weight gain }\end{array}$ \\
\hline Schuller [105] & 1991 & 89 & $\mathrm{R}, \mathrm{C}$ & ALI/ARDS & N/A & $\begin{array}{l}\text { Mortality associated with higher positive fluid } \\
\text { balance }>1 \text { liter over } 36 \mathrm{~h}(50 \mathrm{vs.} 26 \%, \mathrm{p}<0.05) \\
\text { along with longer duration of MV and ICU/ } \\
\text { hospital stay }\end{array}$ \\
\hline Goldstein [88] & 2001 & 21 & $\mathrm{R}, \mathrm{C}$ & Pediatric AKI & N/A & $\begin{array}{l}\text { Mortality associated with higher } \% \mathrm{FO} \text { at } \\
\text { RRT initiation ( } 34 \text { vs. } 16.4 \%, \mathrm{p}=0.03 \text { ) }\end{array}$ \\
\hline Brandstrup [106] & 2003 & 172 & RCT & $\begin{array}{l}\text { Elective } \\
\text { colorectal } \\
\text { surgery }\end{array}$ & $\begin{array}{l}\text { Restrictive vs. } \\
\text { standard peri- } \\
\text { operative fluid } \\
\text { strategy }\end{array}$ & $\begin{array}{l}\text { Restrictive strategy reduced postoperative weight } \\
\text { gain and complications ( } 33 \text { vs. } 51 \%, p=0.003 \text { ) }\end{array}$ \\
\hline Foland [89] & 2004 & 113 & $\mathrm{R}, \mathrm{C}$ & Pediatric AKI & N/A & $\begin{array}{l}\text { Mortality associated with higher } \% \text { FO at } \\
\text { RRT initiation }(15.5 \% \text { vs. } 9.2 \%, p=0.01)\end{array}$ \\
\hline Gillespie [90] & 2004 & 77 & $\mathrm{R}, \mathrm{C}$ & Pediatric AKI & N/A & $\begin{array}{l}\text { Mortality associated with higher } \% \text { FO at } \\
\text { RRT initiation }(>10 \%, \mathrm{RR} 3.02, \mathrm{p}=0.002)\end{array}$ \\
\hline Goldstein [107] & 2005 & 116 & $\mathrm{R}, \mathrm{C}$ & Pediatric AKI & N/A & $\begin{array}{l}\text { Mortality associated with higher \%FO at } \\
\text { RRT initiation ( } 25.4 \text { vs. } 14.2 \%, \mathrm{p}=0.03)\end{array}$ \\
\hline Sakr [78] & 2005 & 393 & $\mathrm{P}, \mathrm{C}$ & ALI/ARDS & N/A & $\begin{array}{l}\text { Mortality associated with positive cumulative } \\
\text { fluid balance }(+4.4 \text { vs. }-3.01, \text { OR } 1.5, p=0.003)\end{array}$ \\
\hline Uchino [108] & 2006 & 331 & $\mathrm{P}, \mathrm{NR}$ & Critically ill & N/A & $\begin{array}{l}\text { Mortality associated with positive fluid } \\
\text { balance (OR } 1.0002 \text { per each } \mathrm{ml} / \text { day, } \mathrm{p}<0.01 \text { ) }\end{array}$ \\
\hline Wiedemann [79] & 2006 & 1,000 & $\mathrm{RCT}$ & ALI/ARDS & $\begin{array}{l}\text { Conservative } \\
\text { vs. liberal } \\
\text { fluid strategy }\end{array}$ & $\begin{array}{l}\text { Conservative strategy had lower cumulative } \\
7 \text {-day fluid balance }(-0.13 \text { vs. } 6.91,<0.001) \text {, } \\
\text { improved gas exchange, shorter time on } \\
\text { ventilator and ICU stay, no difference in rate } \\
\text { of RRT or mortality }\end{array}$ \\
\hline Payen [91] & 2008 & 1,120 & $\mathrm{P}, \mathrm{NR}$ & Critically ill & N/A & $\begin{array}{l}\text { Positive average fluid balance (per } 1 \text { liter } / 24 \mathrm{~h} \text { ) } \\
\text { independently associated with } 60 \text {-mortality } \\
(\mathrm{HR} 1.21, \mathrm{p}<0.001)\end{array}$ \\
\hline
\end{tabular}

$\mathrm{P}=$ Prospective, $\mathrm{R}=$ retrospective $\mathrm{C}=$ cohort $\mathrm{RCT}=$ randomized clinical trial; $\mathrm{NR}=$ non-randomized $; \mathrm{HR}=$ hazard ratio; $\mathrm{ALI}=$ acute lung injury; ARDS = acute respiratory distress syndrome; N/A = not applicable; $\% \mathrm{FO}=$ percentage fluid overload; $\mathrm{RR}=$ risk ratio; $\mathrm{MV}=$ mechanical ventilation. 
and following cardiac surgery. Goldstein et al. [88] retrospectively evaluated 21 critically ill children with AKI requiring CRRT and found that non-survivors had a higher percentage of fluid overload at the time CRRT was initiated (34\% for non-survivors vs. $16.4 \%$ for survivors, $\mathrm{p}=0.03$ ). These findings were subsequently confirmed in two additional studies of critically ill children with AKI where risk of death was significantly increased in those with a greater positive fluid overload at the time CRRT was started [89, 90]. Gillespie et al. [90] conducted a retrospective review of 77 critically ill children who were treated with CVVH. Those with high fluid overload (>10\%) at CVVH initiation had a $>3$-fold risk of death compared to those with little or no fluid overload (HR 3.0, 95\% CI 1.5-6.1, p = 0.002). Foland et al. [89] retrospectively studied 113 critically ill children requiring CVVH. Median percentage fluid overload at the time CRRT was initiated was significantly lower in survivors vs. non-survivors (7.8 vs. $15.1 \%$, $\mathrm{p}=0.02$ ).

Recently, Payen et al. [91] performed a secondary analysis of the Sepsis Occurrence in Acutely Ill Patients (SOAP) study, a large multicenter European observational cohort study, to evaluate the outcomes associated with AKI. Patients were compared by whether they developed AKI, defined according to the renal SOFA score as a creatinine $>3.5 \mathrm{mg} / \mathrm{dl}(309 \mu \mathrm{mol} / \mathrm{l})$ or a urine output $<500 \mathrm{ml} /$ day, or not. In addition, the study evaluated the timing of initiation of RRT and outcomes, where 'early' RRT was defined as commencing $<2$ days and 'delayed' if started $\geq 2$ days after ICU admission. Of the 3,147 patients included in the study, $1,120(36 \%)$ developed AKI at some point during their ICU stay. Mortality at 60 days was $36 \%$ for those with AKI and only $16 \%$ for those with no AKI ( $p<0.01$ ). In patients with AKI, the average daily fluid balance was significantly more positive among non-survivors compared with survivors ( 1,000 vs. $150 \mathrm{ml}, \mathrm{p}<0.001)$. Those with oliguria and those treated with RRT had higher 60-day mortality compared to those without oliguria or having received RRT (oliguria: $41 \%$ for non-survivors vs. $33 \%$ for survivors, $\mathrm{p}<0.01$; RRT: $52 \%$ for non-survivors vs. $32 \%$ for survivors, $\mathrm{p}<0.01$ ). Furthermore, for patients in whom treatment with RRT was started 'early' after admission to ICU, the median length of ICU stay was significantly shorter (6.1 days for early vs. 12.2 days for delayed, $\mathrm{p}<0.001$ ) and 60 -day mortality rate was significantly lower $(44.8 \%$ for early vs. $64.6 \%$ for delayed, $\mathrm{p}<0.01$ ). Attention to fluid balance and prevention of volume overload in critically ill patients with AKI may be an important determinant of outcome. Moreover, the prevention and/or management of volume overload may evolve as a key early trigger for extracorporeal fluid removal independent of solute clearance. This was evident in the recently reported ATN trial, where those allocated to alternate-day less intensive hemodialysis not uncommonly had inadequate control of fluid volume that mandated additional 'off-protocol' ultrafiltration sessions [13].

\section{'Timing' of Discontinuation of RRT}

There is a relative paucity of data about the process of discontinuation of RRT in critically ill patients with AKI. This lack of evidence contrasts with the field of mechanical ventilation, where many studies dealing with the process of 'weaning' from mechanical ventilation have been conducted [92-94].

In the trial by Bouman et al. [46], CRRT was discontinued when the urine output returned to and was stable at $>60 \mathrm{ml} / \mathrm{h}$. However, there was no data on whether discontinuation at different rates of urine output was more or less successful and whether failure to successfully wean from RRT led to variation in survival, renal recovery, re-initiation of RRT or other outcomes. Recently, Wu et al. [95] performed a retrospective case-control study to evaluate the timing of RRT discontinuation in 304 patients treated with IHD. 94 patients (30.9\%) were weaned from RRT for 5 or more days, of which 64 (21.1\%) were free from RRT for $\geq 30$ days. Factors independently associated with re-initiation of RRT within 30 days included: longer duration of RRT, higher SOFA score, oliguria $(\leq 100 \mathrm{ml}$ in $8 \mathrm{~h}$ ) and age $\geq 65$ years.

Recently, the BEST Kidney investigators also evaluated the current practice of CRRT discontinuation to identify which factors present at the time of discontinuation may assist clinicians in predicting successful cessation of CRRT [96]. Approximately $50 \%$ of critically ill patients receiving CRRT had it discontinued while still otherwise undergoing full life-sustaining therapy. Urine output at cessation of CRRT was found to be the most important predictor of successful discontinuation of CRRT. A urine output of $>400 \mathrm{ml} /$ day without concomitant diuretic therapy had the best operative characteristics with a sensitivity, specificity, positive predictive value and negative predictive value of $0.47,0.81,0.81$, and 0.77 , respectively. At this cut-off, $78.6 \%$ were correctly classified. Patients whose CRRT was successfully discontinued without requirement for re-institution of RRT 
were more likely to survive to hospital discharge compared with those requiring re-initiation (71.5 vs. $57.3 \%$, $\mathrm{p}<0.0001)$.

\section{Conclusions}

Despite many studies suggesting that early RRT is associated with improved clinical outcomes in patients with AKI, there are at present no suitably-powered randomized clinical trials to guide clinicians on what defines 'early' and what clinical factors or thresholds are ideal for the decision to initiate RRT 'early' [97]. There is virtually no data to accurately distinguish in advance the injured kidney that will need extracorporeal organ support from the injured kidney that retains capacity for early recovery. Moreover, if there is clinical benefit to early initiation of RRT, it remains unclear whether this benefit may be attributable to earlier clearance and control of uremic toxins and solutes, prevention and management of volume overload, or a combination of both or to addi- tional factors not yet elucidated. Clearly, further studies in this area are needed [97]. These will be challenging to perform and will require a large enough number of subjects to detect clinically relevant differences in key outcomes such as survival and recovery of kidney function. Such a trial should strive to discriminate potential differences in clinical outcome attributable to achieving metabolic control versus fluid balance control. One of the most difficult issues in $\mathrm{AKI}$ is determining the exact time of onset and magnitude and/or severity of injury to the kidney. Regrettably, conventional biomarkers such as serum urea and creatinine perform poorly and are commonly inconsistent [98]. Consequently, new studies evaluating the timing of RRT in AKI should also incorporate newer biomarkers such as neutrophil gelatinase-associated lipocalin (NGAL), kidney injury molecule-1 (KIM1), interleukin-18 (IL-18) and/or cystatin C in order to better determine the onset, severity, persistence and response to intervention for patients with AKI accurately [99-101].

\section{References}

1 Augustine JJ, Sandy D, Seifert TH, Paganini EP: A randomized controlled trial comparing intermittent with continuous dialysis in patients with ARF. Am J Kidney Dis 2004;44: 1000-1007.

-2 Bagshaw SM, Berthiaume LR, Delaney A, Bellomo R: Continuous versus intermittent renal replacement therapy for critically ill patients with acute kidney injury: a metaanalysis. Crit Care Med 2008;36:610-617.

-3 Bellomo R, Angus D, Star RA: The Acute Dialysis Quality Initiative - part II: patient selection for CRRT. Adv Ren Replace Ther 2002;9:255-259.

-4 Bellomo R, Ronco C: Blood purification in the intensive care unit: evolving concepts. World J Surg 2001;25:677-683.

$\checkmark 5$ Cho KC, Himmelfarb J, Paganini E, Ikizler TA, Soroko SH, Mehta RL, Chertow GM: Survival by dialysis modality in critically ill patients with acute kidney injury. J Am Soc Nephrol 2006;17:3132-3138.

-6 Clark WR, Letteri JJ, Uchino S, Bellomo R, Ronco C: Recent clinical advances in the management of critically ill patients with acute renal failure. Blood Purif 2006;24:487498.

$\checkmark 7$ Lameire N, Van Biesen W, Vanholder R: Acute renal failure. Lancet 2005;365:417430.
8 Mehta RL, McDonald B, Gabbai FB, Pahl M, Pascual MT, Farkas A, Kaplan RM: A randomized clinical trial of continuous versus intermittent dialysis for acute renal failure. Kidney Int 2001;60:1154-1163.

-9 Ronco C, Bagshaw SM, Gibney RT, Bellomo $\mathrm{R}$ : Outcome comparisons of intermittent and continuous therapies in acute kidney injury: what do they mean? Int J Artif Organs 2008;31:213-220.

10 Ronco C, Bellomo R, Homel P, Brendolan A, Dan M, Piccinni P, La Greca G: Effects of different doses in continuous veno-venous haemofiltration on outcomes of acute renal failure: a prospective randomised trial. Lancet 2000;356:26-30

-11 Saudan P, Niederberger M, De Seigneux S, Romand J, Pugin J, Perneger T, Martin PY: Adding a dialysis dose to continuous hemofiltration increases survival in patients with acute renal failure. Kidney Int 2006;70:13121317.

12 Schiffl H, Lang SM, Fischer R: Daily hemodialysis and the outcome of acute renal failure. N Engl J Med 2002;346:305-310.

13 VA/NIH Acute Renal Failure Trial Network: Intensity of renal support in critically ill patients with acute kidney injury. $\mathrm{N}$ Engl J Med 2008;359:7-20.
14 Uchino S, Bellomo R, Kellum JA, Morimatsu H, Morgera S, Schetz MR, Tan I, Bouman C, Macedo E, Gibney N, et al: Patient and kidney survival by dialysis modality in critically ill patients with acute kidney injury. Int J Artif Organs 2007;30:281-292.

15 Uehlinger DE, Jakob SM, Ferrari P, Eichelberger M, Huynh-Do U, Marti HP, Mohaupt MG, Vogt B, Rothen HU, Regli B, et al: Comparison of continuous and intermittent renal replacement therapy for acute renal failure. Nephrol Dial Transplant 2005;20:16301637.

16 Vinsonneau C, Camus C, Combes A, Costa de Beauregard MA, Klouche K, Boulain T, Pallot JL, Chiche JD, Taupin P, Landais P, et al: Continuous venovenous haemodiafiltration versus intermittent haemodialysis for acute renal failure in patients with multipleorgan dysfunction syndrome: a multicentre randomised trial. Lancet 2006;368:379-385.

-17 DuBose TD Jr, Warnock DG, Mehta RL, Bonventre JV, Hammerman MR, Molitoris BA, Paller MS, Siegel NJ, Scherbenske J, Striker GE: Acute renal failure in the 21st century: recommendations for management and outcomes assessment. Am J Kidney Dis 1997;29:793-799.

18 Jung B, Blake PG, Mehta RL, Mendelssohn DC: Attitudes of Canadian nephrologists toward dialysis modality selection. Perit Dial Int 1999;19:263-268. 
19 Mehta RL, Letteri JM: Current status of renal replacement therapy for acute renal failure. A survey of US nephrologists. The National Kidney Foundation Council on Dialysis. Am J Nephrol 1999;19:377-382.

-20 Mendelssohn DC, Mullaney SR, Jung B, Blake PG, Mehta RL: What do American nephrologists think about dialysis modality selection? Am J Kidney Dis 2001;37:22-29.

- 21 Overberger P, Pesacreta M, Palevsky PM: Management of renal replacement therapy in acute kidney injury: a survey of practitioner prescribing practices. Clin J Am Soc Nephrol 2007;2:623-630.

-22 Ricci Z, Ronco C, D’Amico G, De Felice R, Rossi S, Bolgan I, Bonello M, Zamperetti N, Petras D, Salvatori G, et al: Practice patterns in the management of acute renal failure in the critically ill patient: an international survey. Nephrol Dial Transplant 2006;21:690696.

23 McCarthy JT: Prognosis of patients with acute renal failure in the intensive-care unit: a tale of two eras. Mayo Clin Proc 1996;71: 117-126.

-24 Teschan PE, Baxter CR, O’Brien TF, Freyhof JN, Hall WH: Prophylactic hemodialysis in the treatment of acute renal failure. Ann Intern Med 1960;53:992-1016.

25 Woodrow G, Turney JH: Cause of death in acute renal failure. Nephrol Dial Transplant 1992;7:230-234.

-26 Askenazi DJ, Feig DI, Graham NM, HuiStickle S, Goldstein SL: Three- to five-year longitudinal follow-up of pediatric patients after acute renal failure. Kidney Int 2006;69: 184-189.

27 Bagshaw SM, George C, Bellomo R: Changes in the incidence and outcome for early acute kidney injury in a cohort of Australian intensive care units. Crit Care 2007;11:R68.

28 Bagshaw SM, Laupland KB, Doig CJ, Mortis G, Fick GH, Mucenski M, Godinez-Luna T, Svenson LW, Rosenal T: Prognosis for longterm survival and renal recovery in critically ill patients with severe acute renal failure: a population-based study. Crit Care 2005;9: R700-R709.

-29 Abosaif NY, Tolba YA, Heap M, Russell J, El Nahas AM: The outcome of acute renal failure in the intensive care unit according to RIFLE: model application, sensitivity, and predictability. Am J Kidney Dis 2005;46: 1038-1048.

-30 Bell M, Liljestam E, Granath F, Fryckstedt J, Ekbom A, Martling CR: Optimal follow-up time after continuous renal replacement therapy in actual renal failure patients stratified with the RIFLE criteria. Nephrol Dial Transplant 2005;20:354-360.

-31 Bellomo R, Kellum JA, Ronco C: Defining and classifying acute renal failure: from advocacy to consensus and validation of the RIFLE criteria. Intensive Care Med 2007;33: 409-413.
32 Bellomo R, Ronco C, Kellum JA, Mehta RL, Palevsky P: Acute renal failure - definition, outcome measures, animal models, fluid therapy and information technology needs: the Second International Consensus Conference of the Acute Dialysis Quality Initiative (ADQI) Group. Crit Care 2004;8:R204R212.

33 Hoste EA, Clermont G, Kersten A, Venkataraman $\mathrm{R}$, Angus DC, De Bacquer D, Kellum JA: RIFLE criteria for acute kidney injury are associated with hospital mortality in critically ill patients: a cohort analysis. Crit Care 2006;10:R73.

34 Hoste EA, Kellum JA: Incidence, classification, and outcomes of acute kidney injury. Contrib Nephrol. Basel, Karger, 2007, vol 156, pp 32-38.

35 Kuitunen A, Vento A, Suojaranta-Ylinen R, Pettila V: Acute renal failure after cardiac surgery: evaluation of the RIFLE classification. Ann Thorac Surg 2006;81:542-546.

36 Lopes JA, Jorge S, Neves FC, Caneira M, da Costa AG, Ferreira AC, Prata MM: An assessment of the rifle criteria for acute renal failure in severely burned patients. Nephrol Dial Transplant 2007;22:285.

- 37 Lopes JA, Jorge S, Silva S, de Almeida E, Abreu F, Martins C, do Carmo JA, Lacerda JF, Prata MM: An assessment of the RIFLE criteria for acute renal failure following myeloablative autologous and allogeneic haematopoietic cell transplantation. Bone Marrow Transplant 2006;38:395.

38 Uchino S, Bellomo R, Goldsmith D, Bates S, Ronco C: An assessment of the RIFLE criteria for acute renal failure in hospitalized patients. Crit Care Med 2006;34:1913-1917.

39 Van Biesen W, Vanholder R, Lameire N: Defining acute renal failure: RIFLE and beyond. Clin J Am Soc Nephrol 2006;1:1314-1319.

40 Bagshaw SM, George C, Dinu I, Bellomo R: A multi-centre evaluation of the RIFLE criteria for early acute kidney injury in critically ill patients. Nephrol Dial Transplant 2008; 23:1203-1210.

41 Bagshaw SM, George C, Bellomo R: Early acute kidney injury and sepsis: a multicentre evaluation. Crit Care 2008;12:R47.

42 Kellum JA, Levin N, Bouman C, Lameire N: Developing a consensus classification system for acute renal failure. Curr Opin Crit Care 2002;8:509-514.

43 Hoste EA, Kellum JA: Acute kidney injury: epidemiology and diagnostic criteria. Curr Opin Crit Care 2006;12:531-537.

44 Bagshaw SM, Gibney RT: Ideal determinants for the initiation of renal replacement therapy: timing, metabolic threshold or fluid balance? Acta Clin Belg Suppl 2007:357-361.

45 Bagshaw SM, Uchino S, Bellomo R, Morimatsu H, Morgera S, Schetz M, Tan I, Bouman C, Macedo E, Gibney N, et al: Timing of renal replacement therapy and clinical outcomes in critically ill patients with severe acute kidney injury. J Crit Care 2008; in press, available online April 18, 2008.
46 Bouman CS, Oudemans-Van Straaten HM, Tijssen JG, Zandstra DF, Kesecioglu J: Effects of early high-volume continuous venovenous hemofiltration on survival and recovery of renal function in intensive care patients with acute renal failure: a prospective, randomized trial. Crit Care Med 2002; 30:2205-2211.

47 Gibney N, Hoste E, Burdmann EA, Bunchman T, Kher V, Viswanathan R, Mehta RL, Ronco C: Timing of initiation and discontinuation of renal replacement therapy in AKI: unanswered key questions. Clin J Am Soc Nephrol 2008;3:876-880.

48 Guerin C, Girard R, Selli JM, Perdrix JP, Ayzac L: Initial versus delayed acute renal failure in the intensive care unit. A multicenter prospective epidemiological study. Rhone-Alpes Area Study Group on Acute Renal Failure. Am J Respir Crit Care Med 2000;161:872-879.

49 Mehta RL, Pascual MT, Soroko S, Savage BR, Himmelfarb J, Ikizler TA, Paganini EP, Chertow GM: Spectrum of acute renal failure in the intensive care unit: the PICARD experience. Kidney Int 2004;66:1613-1621.

50 Palevsky PM: Clinical review: timing and dose of continuous renal replacement therapy in acute kidney injury. Crit Care 2007;11: 232.

51 Uchino S, Kellum JA, Bellomo R, Doig GS, Morimatsu H, Morgera S, Schetz M, Tan I, Bouman C, Macedo E, et al: Acute renal failure in critically ill patients: a multinational, multicenter study. JAMA 2005;294:813818.

52 Andrade L, Cleto S, Seguro AC: Door-to-dialysis time and daily hemodialysis in patients with leptospirosis: impact on mortality. Clin J Am Soc Nephrol 2007;2:739-744.

53 Brivet FG, Kleinknecht DJ, Loirat P, Landais PJ: Acute renal failure in intensive care units - causes, outcome, and prognostic factors of hospital mortality; a prospective, multicenter study. French Study Group on Acute Renal Failure. Crit Care Med 1996;24:192198.

54 Cosentino F, Chaff C, Piedmonte M: Risk factors influencing survival in ICU acute renal failure. Nephrol Dial Transplant 1994; 9(suppl 4):179-182.

55 Demirkilic U, Kuralay E, Yenicesu M, Caglar K, Oz BS, Cingoz F, Gunay C, Yildirim V, Ceylan S, Arslan M, et al: Timing of replacement therapy for acute renal failure after cardiac surgery. J Card Surg 2004;19:17-20.

56 Elahi MM, Lim MY, Joseph RN, Dhannapuneni RR, Spyt TJ: Early hemofiltration improves survival in post-cardiotomy patients with acute renal failure. Eur J Cardiothorac Surg 2004;26:1027-1031.

57 Gettings LG, Reynolds HN, Scalea T: Outcome in post-traumatic acute renal failure when continuous renal replacement therapy is applied early vs. late. Intensive Care Med 1999;25:805-813. 
-58 Kresse S, Schlee H, Deuber HJ, Koall W, Osten B: Influence of renal replacement therapy on outcome of patients with acute renal failure. Kidney Int Suppl 1999:S75-S78.

59 Liu KD, Himmelfarb J, Paganini EP, Ikizler A, Soroko S, Mehta RL, Chertow GM: Timing of initiation of dialysis in critically ill patients with acute kidney injury. CJASN 2006; 1:915-919.

60 Page B, Vieillard-Baron A, Chergui K, Peyrouset $\mathrm{O}$, Rabiller A, Beauchet A, Aegerter P, Jardin F: Early veno-venous haemodiafiltration for sepsis-related multiple organ failure. Crit Care 2005;9:R755-R763.

61 Silvester W, Bellomo R, Cole L: Epidemiology, management, and outcome of severe acute renal failure of critical illness in Australia. Crit Care Med 2001;29:1910-1915.

62 Splendiani G, Mazzarella V, Cipriani S, Zazzaro D, Casciani CU: Continuous renal replacement therapy: our experience in intensive care unit. Ren Fail 2001;23:259-264.

63 Sugahara S, Suzuki H: Early start on continuous hemodialysis therapy improves survival rate in patients with acute renal failure following coronary artery bypass surgery. Hemodialysis Int 2004;8:320-325.

64 Bagshaw SM, Gibney RT: Conventional markers of kidney function. Crit Care Med 2008;36:S152-S158.

65 Abuelo JG: Normotensive ischemic acute renal failure. N Engl J Med 2007;357:797-805.

-66 Sacks H, Chalmers TC, Smith H Jr: Randomized versus historical controls for clinical trials. Am J Med 1982;72:233-240.

-67 Fischer RP, Griffen WO Jr, Reiser M, Clark DS: Early dialysis in the treatment of acute renal failure. Surg Gynecol Obstet 1966;123: 1019-1023.

68 Gillum DM, Dixon BS, Yanover MJ, Kelleher SP, Shapiro MD, Benedetti RG, Dillingham MA, Paller MS, Goldberg JP, Tomford RC: The role of intensive dialysis in acute renal failure. Clin Nephrol 1986;25:249-255.

69 Kleinknecht D, Jungers P, Chanard J, Barbanel C, Ganeval D: Uremic and non-uremic complications in acute renal failure: evaluation of early and frequent dialysis on prognosis. Kidney Int 1972;1:190-196.

-70 Parsons FM, Hobson SM, Blagg CR, McCracken BH: Optimum time for dialysis in acute reversible renal failure. Description and value of an improved dialyser with large surface area. Lancet 1961;i:129-134.

71 Conger JD: A controlled evaluation of prophylactic dialysis in post-traumatic acute renal failure. J Trauma 1975;15:1056-1063.

-72 Bent P, Tan HK, Bellomo R, Buckmaster J, Doolan L, Hart G, Silvester W, Gutteridge G, Matalanis G, Raman J, et al: Early and intensive continuous hemofiltration for severe renal failure after cardiac surgery. Ann Thorac Surg 2001;71:832-837.
73 Liano F, Gallego A, Pascual J, Garcia-Martin F, Teruel JL, Marcen R, Orofino L, Orte L, Rivera M, Gallego N, et al: Prognosis of acute tubular necrosis: an extended prospectively contrasted study. Nephron 1993; 63:21-31.

74 Dellinger RP, Levy MM, Carlet JM, Bion J, Parker MM, Jaeschke R, Reinhart K, Angus DC, Brun-Buisson C, Beale R, et al: Surviving Sepsis Campaign: international guidelines for management of severe sepsis and septic shock: 2008. Crit Care Med 2008;36: 296-327.

-75 Kellum JA, Cerda J, Kaplan LJ, Nadim MK Palevsky PM: Fluids for prevention and management of acute kidney injury. Int J Artif Organs 2008;31:96-110.

76 Rivers E, Nguyen B, Havstad S, Ressler J, Muzzin A, Knoblich B, Peterson E, Tomlanovich M: Early goal-directed therapy in the treatment of severe sepsis and septic shock. N Engl J Med 2001;345:1368-1377.

77 Van Biesen W, Yegenaga I, Vanholder R, Verbeke F, Hoste E, Colardyn F, Lameire N: Relationship between fluid status and its management on acute renal failure in intensive care unit patients with sepsis: a prospective analysis. J Nephrol 2005;18:5460.

-78 Sakr Y, Vincent JL, Reinhart K, Groeneveld J, Michalopoulos A, Sprung CL, Artigas A, Ranieri VM: High tidal volume and positive fluid balance are associated with worse outcome in acute lung injury. Chest 2005;128 3098-3108.

79 Wiedemann HP, Wheeler AP, Bernard GR Thompson BT, Hayden D, deBoisblanc B, Connors AF Jr, Hite RD, Harabin AL: Comparison of two fluid-management strategies in acute lung injury. N Engl J Med 2006;354: 2564-2575.

80 Gibney N, Cerda J, Davenport A, Ramirez J, Singbartl K, Leblanc M, Ronco C: Volume management by renal replacement therapy in acute kidney injury. Int J Artif Organs 2008;31:145-155.

81 Jaeger JQ, Mehta RL: Assessment of dry weight in hemodialysis: an overview. J Am Soc Nephrol 1999; 10:392-403.

82 Kellum JA, Ronco C, Mehta RL: Fluid management in acute kidney injury. Int J Artif Organs 2008;31:94-95.

83 Mehta RL, Clark WC, Schetz M: Techniques for assessing and achieving fluid balance in acute renal failure. Curr Opin Crit Care 2002;8:535-543

84 Pinsky MR, Brophy P, Padilla J, Paganini E, Pannu N: Fluid and volume monitoring. Int J Artif Organs 2008;31:111-126.

85 Bagshaw SM, Bellomo R, Kellum JA: Oliguria, volume overload, and loop diuretics. Crit Care Med 2008, 36:S172-S178.

$>86$ Upadya A, Tilluckdharry L, Muralidharan V, Amoateng-Adjepong Y, Manthous CA: Fluid balance and weaning outcomes. Intensive Care Med 2005;31:1643-1647.
87 Alsous F, Khamiees M, DeGirolamo A, Amoateng-Adjepong Y, Manthous CA: Negative fluid balance predicts survival in patients with septic shock: a retrospective pilot study. Chest 2000;117:1749-1754.

88 Goldstein SL, Currier H, Graf C, Cosio CC, Brewer ED, Sachdeva R: Outcome in children receiving continuous venovenous hemofiltration. Pediatrics 2001;107:13091312 .

-89 Foland JA, Fortenberry JD, Warshaw BL, Pettignano R, Merritt RK, Heard ML, Rogers K, Reid C, Tanner AJ, Easley KA: Fluid overload before continuous hemofiltration and survival in critically ill children: a retrospective analysis. Crit Care Med 2004;32:17711776 .

90 Gillespie RS, Seidel K, Symons JM: Effect of fluid overload and dose of replacement fluid on survival in hemofiltration. Pediatr Nephrol 2004;19:1394-1399.

$\checkmark 91$ Payen D, de Pont AC, Sakr Y, Spies C, Reinhart K, Vincent JL: A positive fluid balance is associated with a worse outcome in patients with acute renal failure. Crit Care 2008;12:R74

92 Brochard L, Rauss A, Benito S, Conti G, Mancebo J, Rekik N, Gasparetto A, Lemaire F: Comparison of three methods of gradual withdrawal from ventilatory support during weaning from mechanical ventilation. Am J Respir Crit Care Med 1994;150:896-903.

93 Esteban A, Alia I, Tobin MJ, Gil A, Gordo F, Vallverdu I, Blanch L, Bonet A, Vazquez A, de Pablo R, et al: Effect of spontaneous breathing trial duration on outcome of attempts to discontinue mechanical ventilation. Spanish Lung Failure Collaborative Group. Am J Respir Crit Care Med 1999;159: 512-518.

94 Esteban A, Frutos F, Tobin MJ, Alia I, Solsona JF, Valverdu I, Fernandez R, de la Cal MA, Benito S, Tomas R, et al: A comparison of four methods of weaning patients from mechanical ventilation. Spanish Lung Failure Collaborative Group. N Engl J Med 1995; 332:345-350.

$\checkmark 95$ Wu VC, Ko WJ, Chang HW, Chen YW, Lin YF, Shiao CC, Chen YM, Chen YS, Tsai PR, $\mathrm{Hu}$ FC, et al: Risk factors of early redialysis after weaning from postoperative acute renal replacement therapy. Intensive Care Med 2008;34:101-108.

96 Uchino S, Bellomo R, Morimatsu H, Morgera S, Schetz M, Tan I, Bouman C, Macedo E, Gibney N, Tolwani A, et al: Discontinuation of continuous renal replacement therapy: a prospective multi-center observational study. Crit Care Med 2008 (in press).

$\checkmark 97$ Seabra VF, Balk EM, Liangos O, Sosa MA, Cendoroglo M, Jaber BL: Timing of renal replacement therapy initiation in acute renal failure: a meta-analysis. Am J Kidney Dis 2008;52:272-284 
98 Bagshaw SM, Bellomo R: Early diagnosis of acute kidney injury. Curr Opin Crit Care 2007;13:638-644.

99 Bagshaw SM, Langenberg C, Haase M, Wan L, May CN, Bellomo R: Urinary biomarkers in septic acute kidney injury. Intensive Care Med 2007;33:1285-1296.

100 Bonventre JV: Diagnosis of acute kidney injury: from classic parameters to new biomarkers. Contrib Nephrol. Basel, Karger, 2007, vol 156, pp 213-219.

101 Devarajan P: Emerging biomarkers of acute kidney injury. Contrib Nephrol. Basel, Karger, 2007, vol 156, pp 203-212.

102 Lange HW, Aeppli DM, Brown DC: Survival of patients with acute renal failure requiring dialysis after open heart surgery: early prognostic indicators. Am Heart J 1987;113:1138-1143.
103 Tsai H, Wu VC, Yang M, Lin Y, Lo W, Wu $\mathrm{K}$ : Outcome in acute liver failure patients treated with renal replacement therapy for acute renal failure: comparison between early or late dialysis (abstract). J Am Soc Nephrol 2005;16:541A.

-104 Simmons RS, Berdine GG, Seidenfeld JJ, Prihoda TJ, Harris GD, Smith JD, Gilbert TJ, Mota E, Johanson WG Jr: Fluid balance and the adult respiratory distress syndrome. Am Rev Respir Dis 1987;135:924929.

105 Schuller D, Mitchell JP, Calandrino FS, Schuster DP: Fluid balance during pulmonary edema. Is fluid gain a marker or a cause of poor outcome? Chest 1991;100: 1068-1075.

106 Brandstrup B, Tønnesen H, Beier-Holgersen R, Hjortsø E, Ørding H, Lindorff-Larsen $\mathrm{K}$, Rasmussen MS, Lanng C, Wallin L, Iversen LH, et al: Effects of intravenous fluid restriction on postoperative complications: comparison of two perioperative fluid regimens: a randomized assessor-blinded multicenter trial. Ann Surg 2003;238:641648.
107 Goldstein SL, Somers MJ, Baum MA, Symons JM, Brophy PD, Blowey D, Bunchman TE, Baker C, Mottes T, McAfee N, et al: Pediatric patients with multi-organ dysfunction syndrome receiving continuous renal replacement therapy. Kidney Int 2005;67:653-658.

108 Uchino S, Bellomo R, Morimatsu H, Sugihara M, French C, Stephens D, Wendon J, Honore P, Mulder J, Turner A: Pulmonary artery catheter versus pulse contour analysis: a prospective epidemiological study. Crit Care 2006;10:R174.

109 Zolwani AJ, Campbell RC, Stofan BS, Lai KR, Oster RA, Wille KM: Standard versus high-dose CVVHDF for ICU-related acute renal failure. J Am Soc Nephrol 2008;19: 1233-1238. 